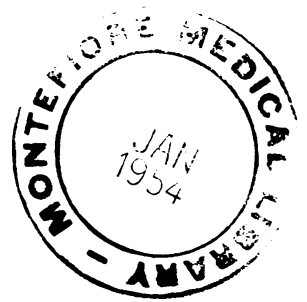

\title{
THE BRAIN-STEM LESIONS IN PARKINSONISM
}

BY

\author{
J. G. GREENFIELD and FRANCES D. BOSANQUET \\ From the National Hospital, Queen Square, and the Department of Pathology, Radcliffe Infirmary \\ and the Nuffield Department of Surgery, University of Oxford
}

The pathological basis for the symptoms of Parkinsonism has been the subject of much study during the last 35 years. Among the monographs devoted to it the most important are those of Trétiakoff (1919), Lewy (1923), Foix and Nicolesco (1925), Hallervorden (1935), Hassler (1938), and Klaue (1940). Four main questions are debated by these and other authors : (1) Whether the symptoms of Parkinsonism are chiefly due to lesions in the corpus striatum and globus pallidus or to lesions in the pigmented cells of the brain-stem, especially the substantia nigra. (2) Whether the lesions seen in cases of idiopathic paralysis agitans are merely the common lesions of senility with a special incidence on certain groups or types of nerve cells. (3) Whether the lesions of idiopathic paralysis agitans are specific for the disease or in any way characteristic of it. (4) Whether the differences between the lesions found in idiopathic, presenile Parkinsonism (paralysis agitans) on the one hand, and those seen in cases with an earlier onset and especially those following an attack of encephalitis lethargica, are qualitative or merely quantitative. Our investigation has been chiefly directed to finding an answer to the last three of these questions.

\section{Literature on the Nature of the Brain-stem Lesions in Parkinsonism}

As the literature of Parkinsonism has been recently discussed in relation to the localization of the lesions by Denny-Brown (1946), it is unnecessary to go into it from this point of view. It is remarkable that neither he nor any other writer in the English language mentions the curious and characteristic types of cell degeneration which may be found in the nuclei of the brain-stem in Parkinsonism. The history of these goes back to 1912, when Lewy described his findings in idiopathic paralysis agitans. He described loss of nerve cells in the lenticular and caudate nuclei with neurofibrillary changes in some of the remaining cells (Lewy, 1913). In the nucleus substantiae innominatae he found fatty and neurofibrillary changes in the nerve cells, and here as well as in the dorsal vagal nucleus there were spherical intra- and extra-cellular bodies which he likened to the "corpora amylacea" found by Lafora $(1911,1913 a)$ in nerve cells in cases of myoclonus epilepsy. It is probable that Lewy's extracellular bodies were ordinary corpora amylacea ; his intra-cellular bodies were shown by Lafora (1913b) to differ from those he had previously described in myoclonus epilepsy in certain staining reactions. Lafora found them in the cells of the oculomotor nucleus in one of which he figured 12 such bodies. He called them hyaline bodies ("cuerpos hialinos") and noted that the peripheral unstained zone was anisotropic. These corrections were accepted by Lewy in his later monograph (1923). Trétiakoff (1919), who found constant lesions in the substantia nigra in nine cases of idiopathic paralysis agitans, appears to have been the first to see these inclusions in the pigmented cells of the mid-brain. He called them Lewy bodies ("corps de Lewy"). He described other forms of cell degeneration, e.g., loss of melanin pigment, swelling, and chromatolysis of the pigmented nerve cells going on either to acute hyaline degeneration or to granular degeneration, or in other cases to what he called "dégénérescence grumeleuse". In this form of degeneration the nucleus disappears and the cytoplasm takes on the appearance of granules and is surrounded by a thin, brilliant envelope formed, as he thought, by neuroglial fibrils. In other cases he saw appearances which he interpreted as fragmentation and hypertrophy of neurofibrils in the cells. Occasional binucleated nerve cells and rare vacuolated nerve cells were also seen. It is noteworthy that he as well as Lewy and Lafora used variants of Mallory's trichrome method. Most later workers appear to have been content with Nissl's method or one of its variants and silver impregnation by the methods of Bielschowsky or von Braunmühl. 
Foix and Nicolesco (1925) also found " absolutely constant "lesions in the substantia nigra in cases of idiopathic paralysis agitans ("la maladie de Parkinson proprement dite"). They described shrinkage of the pigmented cells and chromatolysis with displacement of the nucleus. "It is not rare to find in degenerated cells one or more endo-protoplasmic vacuoles." "Ghost cells" were seen. In silverstained sections neurofibrillary changes were seen and also " inclusions endo-cellulaires de la taille d'un corps amylacé". In the locus coeruleus neurofibrillary changes were easily seen. The pigmented cells of the dorsal vagal nucleus were also degenerated, often with vacuolation, by contrast with the non-pigmented cells in this nucleus which remained healthy. Vacuolation, neurofibrillary changes, and cellular inclusions were also seen in the substantia innominata of Reichert. It appears from this description that cellular inclusions were only seen in sections stained by silver, and it is probable that the "vacuoles" described in sections stained by Nissl's method were really of the same nature.

Fényes (1932) described neurofibrillary tangles in a 28-year-old woman with post-encephalitic Parkinsonism. This change was not seen in the substantia nigra but was found in many other nuclei of the brain-stem. He gives beautiful illustrations of Bielschowsky preparations.

Hallervorden $(1933,1935)$ studied the brains of 21 cases of post-encephalitic Parkinsonism and constantly found neurofibrillary changes in the substantia nigra and also usually in the tegmentum pontis. Senile plaques were never seen in these cases and similar changes in the cortical nerve cells were very rare. In patients over 50 spherical inclusions (Kugeln) sometimes with concentric lamination (Schichtung) might also be seen. They were present without accompanying neurofibrillary change in three patients aged 58, 59, and 61 at death ; apparently these also were post-encephalitic cases. Hallervorden thought that these "Kugeln" resembled the argentophilic ball-like "inclusions" seen in Pick's disease, in which they may also be found in the brain-stem. He considered them part of a process of ageing and no more specific for Parkinsonism than the neurofibrillary change.

Hassler (1937) mapped the various cell groups of the substantia nigra and then (1938) studied the pathology of Parkinsonism in relation to this and to the normal senium. His material consisted of nine brains from cases of presenile paralysis agitans in the collection of the Vogts, 10 cases previously described by the Vogts under the name of "status desintegrationis ", and 11 cases of post-encephalitic Parkinsonism. In two cases of the first group the corpus striatum was quite intact, but in other cases changes in the striatum were related in severity to the tremor. In three cases the globus pallidus also was intact. In other cases lipoid excess or other degenerative changes were seen, but were no more severe than in other senile brains. The nucleus substantiae innominatae showed severe cell loss in one case, and constant change of slighter degree, but more severe than that of the normal senium, in the others. Loss of many cells and severe degenerative changes in those that remained was found in the locus coeruleus in every case. He associated these changes with the symptoms in the autonomic system found in Parkinsonism. The dorsal nucleus of the vagus also showed severe cell loss in the one case in which it could be examined. The substantia nigra seemed to him to be more related to the disease than any other grey matter, as judged by the extent, severity, and constancy of the lesions in this nucleus. The chief brunt of the attack fell on the central cell groups at all levels of the stratum compactum. Some of these groups were completely destroyed in every case ; others contained about half their normal quota of cells. The cases previously described by the Vogts showed very similar changes. In the post-encephalitic cases also the substantia nigra was more severely damaged than other grey nuclei. He described in considerable detail corpora hyaloidea, like those seen by Lewy in the dorsal vagal nucleus, saying that he had never seen these structures in normal senile brains. Lamination was seen in many, and a central knot staining light blue with cresyl violet was sometimes seen in the inclusions in the locus coeruleus. Though he did not consider these bodies to be specific for paralysis agitans, he considered that their presence weakened the theory that the pathogenesis of paralysis agitans was simply a special localization of the usual processes of senescence. (Hassler's findings have been described at some length both because of the thoroughness of his work, and because very few copies of the journal containing it exist outside Germany.)

Klaue (1940), working in the laboratory of Spatz, attacked the question of whether the lesions of paralysis agitans could be distinguished from those of post-encephalitic Parkinsonism. He also described the inclusions in the substantia nigra and locus coeruleus, and saw a concentric pattern in those in the locus coeruleus, but found no difference in this respect between the two diseases. He was unable to find neurofibrillary changes. His work confirmed that of Hassler regarding the constancy of cell loss in the substantia nigra compacta ; this he found to be greatest $(a)$ in the caudal part of the 
nucleus, in islands of cells lying between better preserved medial and lateral groups, and $(b)$ in the oral part, in the most medial cell groups. He concluded that the changes in idiopathic, and those in post-encephalitic, Parkinsonism only differed quantitatively; he found no qualitative difference.

Von Braunmühl (1949) has recently confirmed Hallervorden's opinion on the constancy of neurofibrillary changes in post-encephalitic Parkinsonism and the presence of inclusions (Kugeln) especially in older subjects and also, in his opinion, in younger patients in whom the original attack of the disease was specially severe. Neurofibrillary changes were found in post-encephalitic cases in order of frequency in the substantia nigra, locus coeruleus, tegmentum pontis, corpora quadrigemina, hypothalamus, nuclei round the third ventricle, corpus Luysii, nucleus ruber, pallidum, corpus striatum, nucleus dentatus, cornu Ammonis, insula, and lastly the rest of the cerebral cortex. Both neurofibrillary changes and spherical inclusions were considered to be due to a process of synaeresis which might affect at an unusually early age nerve cells which had been subjected to inflammation.

Spherical inclusions in the nerve cells of the sulstantia nigra were described in the American literature by Helfand (1935) and in the French by van Bogaert (1939-40) in cases of status pigmentatus (Hallervorden-Spatz disease) but neither author gives sufficient details of the staining reactions of the bodies to make possible any decision as to their nature. Davison (1942), in describing eight cases of idiopathic Parkinsonism, describes "vacuolization " of cells in the zona compacta substantiae nigrae, but his Fig. 126 shows a definitely concentric structure within a "vacuole".

Beheim-Schwarzbach (1952) examined the locus coeruleus in 36 brains from patients with a Parkinsonian syndrome and in $\mathbf{3 0}$ other senile and presenile brains from the Vogt collection. In all the 16 brains, which showed the nigral changes typical of true paralysis agitans, "Masson positive vacuoles" (i.e. cytoplasmic inclusions with a red-staining central core) were present in the pigmented cells of the locus coeruleus. They were not found in 13 cases of post-encephalitic Parkinsonism nor in seven cases of "supra-nigral" Parkinsonism. Neurofibrillary changes of Alzheimer type were found in four cases of true paralysis agitans and in all the 20 other cases of Parkinsonism. "Masson positive vacuoles" (Lewy inclusions) were found in the locus coeruleus of a patient with "presenile status marmoratus" aged 59 at death, and in nine brains from other patients aged from 76 to 100 ; most were from patients who died in mental hospitals, but the 100 -year-old patient was stated to have always been healthy. In 19 of the 30 control brains Alzheimer neurofibrillary changes were present ; they were combined with Lewy inclusions in six senile brains.

\section{Material and Methods}

Our material consisted of 19 cases of idiopathic paralysis agitans, 10 cases with a history of an attack of encephalitis lethargica, and five atypical cases. As our examination appeared to show some differences in histological changes between idiopathic and post-encephalitic Parkinsonism it was important that the clinical diagnosis should be as exact as possible. Our idiopathic group is fairly uniform but includes one case, with a constantly positive Wassermann reaction, in which, however, no obviously syphilitic lesions could be found in the brain, and one case in which abundant senile plaques, typical of Alzheimer's disease, were present in the cortex and thalamus; none of the changes of Alzheimer's disease were found in the brain-stem, where the lesions were similar to those seen in the other cases of uncomplicated paralysis agitans. We have limited the post-encephalitic group to cases with a definite history of encephalitis lethargica between the years 1918 and 1924 .

There were left five atypical cases of Parkinsonism. In one of these (No. 33) which has already been published (Critchley and Greenfield, 1948) symptoms of Parkinsonism appeared in the course of olivoponto-cerebellar degeneration. There were two cases (Nos. 31 and 32) of amyotrophy associated with Parkinsonism. In No. 31 there was a history of forced adversive movements of the eyes (? oculogyric crises) but no history of encephalitis. In No. 32 symptoms of Parkinsonism had come on 23 years previously, two years after a short febrile illness in 1926 which left diplopia for some months. This may have been encephalitis lethargica or disseminated sclerosis, of which a few apparently typical plaques were found in the brain and cord. The amyotrophy in this case was due to hypertrophic neuritis of the Dejerine-Sottas type. These two cases will be the subject of independent reports.

The other two cases (Nos. 30 and 34) are put into the atypical group less for clinical reasons than because the lesions in the substantia nigra were very severe and resembled those of the postencephalitic cases, although the duration of symptoms was quite short (two and three years).

As controls, we examined the brain-stems of 19 patients dying between the ages of 50 and 88 years. All had signs of disease of the central nervous 
system, but no clinical evidence of Parkinsonism (Table V).

Some of our material consisted of celloidin sections from post-mortem cases at the National Hospital, Queen Square, before 1939. In these cases no material was available for staining methods other than those already used, which were, in all cases, a Nissl stain with toluidin blue or thionin, and iron haematoxylin with van Gieson. In some cases Mallory's phosphotungstic acid haematoxylin had also been used.

In the post-war material a larger range of staining techniques was used on paraffin or celloidin sections. Various silver techniques were used when neurofibrillary tangles were seen or expected. Lendrum's phloxin-tartrazine method and Heidenhain's azan were found to be of special service in demonstrating the concentric character of some of the spherical inclusions, which was also shown up remarkably well by Masson's trichrome stain. Haematoxylin and eosin was also quite useful for this purpose.

\section{Site of the Main Cell Changes}

Basal Ganglia.-We have examined the mid-brain and pons more thoroughly than the basal ganglia and have omitted examination of the frontal cortex (area 6) in which Benda and Cobb (1942) found constant lesions. An accurate assessment of the degree of damage to the basal ganglia, as of that to the brain-stem, can only be obtained by careful quantitative studies made on serial sections in well defined planes, and compared with exactly similar sections of normal cases in the same age group. We have not attempted this for the basal ganglia, but have examined sections of this region of the brain in most of our cases both of idiopathic and post-encephalitic Parkinsonism as well as in cases of other diseases associated with involuntary movements. This examination has shown the lesions in the basal ganglia in our cases of idiopathic Parkinsonism to be slight by comparison with those in the brain-stem, and to differ in no respect from those found in many senile and presenile brains from cases with no symptoms of Parkinsonism. In postencephalitic cases the lesions in the basal ganglia are often more definite, but in them also they are much slighter than those in the substantia nigra. In this we agree with most of those who have worked on the subject during the past 25 years, that is in the period since the frequency of vascular and perivascular lesions and of some degree of cell loss in the globus pallidus and corpus striatum in older subjects has been recognized.
Substantia Nigra and Locus Coeruleus.-There is general agreement that in post-encephalitic Parkinsonism the substantia nigra is severely damaged and in some cases is reduced to a glial scar in which very few pigmented cells can be seen. In idiopathic paralysis agitans the lesions in the substantia nigra, although usually less severe than in post-encephalitic cases, are always very evident when the various cell groups in this nucleus are compared with the normal (Fig. 1). They also show a remarkable constancy both in the localization and in the nature of the degeneration in these pigmented nerve cells. All writers seem to be agreed that the cell loss is greatest in, or may be confined to, the zona compacta. Hassler found the greatest and most constant cell loss in the cell groups lying in the ventrointernal part of the lateral half of the zona compacta.

We were only able to use serial sections in two cases of idiopathic paralysis agitans. These, when compared with serial sections of the mid-brain of a patient of the same age, showed great cell loss in the parts of the substantia nigra compacta emphasized by Hassler, and also extending beyond these cell groups. In the other cases we could examine sections at one or two levels only. In these the cella loss varied greatly in degree but was usually considerable. Characteristically, especially in the less $\_$ severely affected cases, individual cell groups tended to disappear more or less completely, while those on either side of them showed only slight or moderate cell loss. This localized type of cell loss is apt to give a false impression of normality unless. sections are carefully compared with normal sections at a similar level. In a few cases of idiopathic type and in many post-encephalitic cases, the cell loss was so great that very few pigmented cells were left in the substantia nigra. There was usually also some cell loss in the locus coeruleus, but this was considerably less than that in the substantia nigra. The nucleus pigmentatus tegmentopeduncularis (Riley, 1943) or "formation cupuliforme" (Foix and Nicolesco) which cups the red nucleus and is considered to be an outlying part of the substantia nigra, also showed lesions in some cases.

\section{Types of Change Seen in Nerve Cells of the Brain-stem}

Five main types of change were seen in the nerve cells of the brain-stem, especially the pigmented cells of the substantia nigra and locus coeruleus. These correspond with those found by earlier authors, although some authors confine their description to one or two of these types. 


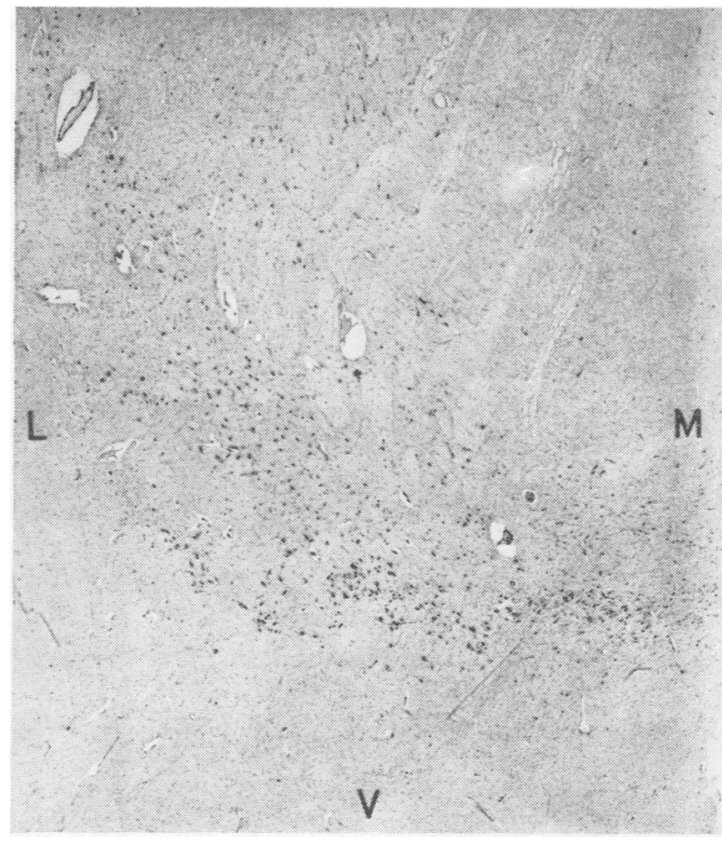

a

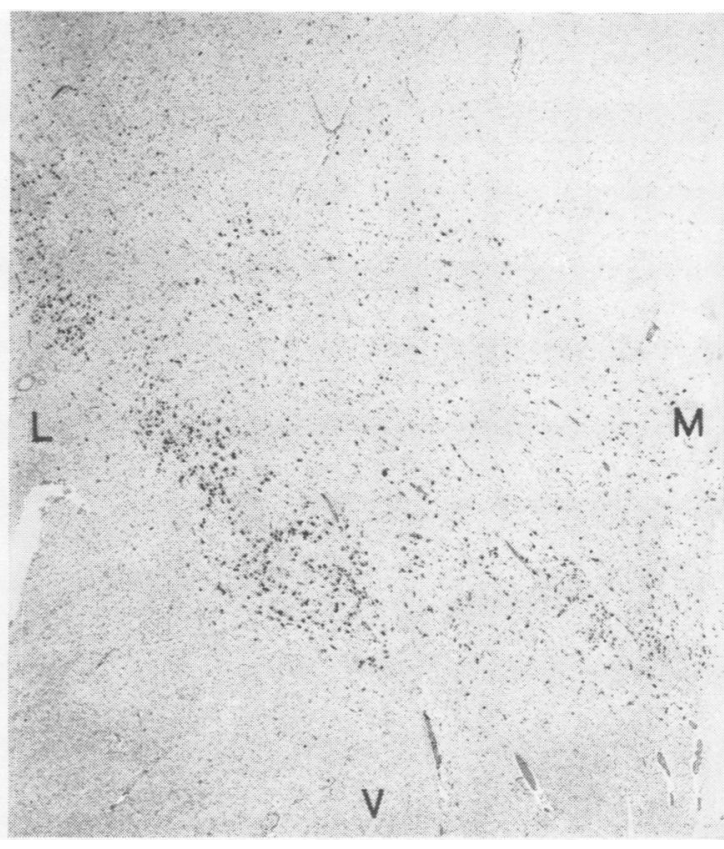

$b$

Fig. 1.-Substantia nigra at level of emergence of oculo-motor nerve. (a) Case 4. (b) normal, aged 52. Nissl stain. Note the three main groups in the lateral half of the stratum compactum in the normal; these have lost most of their nerve cells in the case of idiopathic paralysis agitans. $\mathbf{M}=$ medial. $\quad \mathbf{V}=$ ventral. $\mathbf{L}=$ lateral.

Saccules of Lipochrome Granules.-Saccules of lipochrome granules were often seen, especially in post-encephalitic cases. These may be about the same size as the normal pigmented cells in their vicinity, or may be considerably larger up to $60 \times$ $40 \mu$ (Fig. 2). They have a sharply defined outline which is probably formed by the surrounding neuroglial tissue. Although in many it is difficult

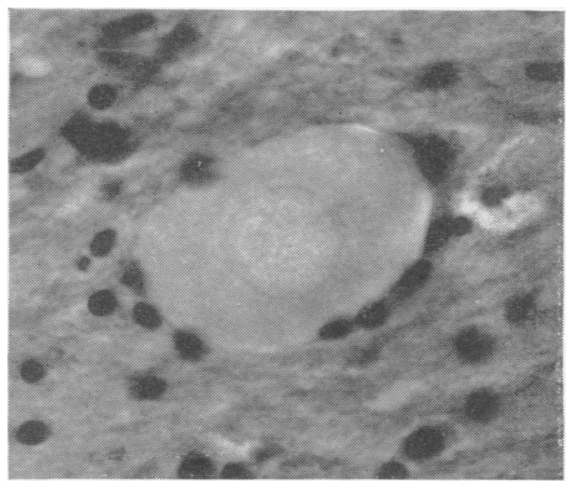

Fig. 2.-Case 21. Saccule in substantia nigra. Haematoxylin-van Gieson. $\times 500$. to be certain that no nucleus is present, as the size of the saccule would allow the nucleus to be above or below the plane of the section, a few examples were seen containing the ghosts of nuclei, indicating that the nucleus degenerates and disappears. They contain no melanin. These saccules appear to correspond to the " dégénérescence grumeleuse" of Trétiakoff, who considered this change to be peculiar to the cells of the substantia nigra. As his thesis was written during the early years of the epidemic of encephalitis lethargica and before cases of the type later known as post-encephalitic Parkinsonism were recognized, it would appear that he found this change in cases of idiopathic paralysis agitans. In our material granular saccules were most numerous in post-encephalitic cases.

In many cases of all types of Parkinsonism the cells of the substantia nigra and locus coeruleus contain an excess of lipochrome granules which may collect in a rounded mass between the nucleus and the melanin or even among the melanin granules. The formation of saccules appears to be a further development of this process, and it is difficult to decide at what stage the range of normality is exceeded. For this reason we did not attempt to decide in which cases saccules were present and in 
which they were absent. When, however, fairly numerous oval or rounded saccules containing nothing except lipochrome granules were found, the appearances were evidently abnormal. Such cases are noted in Tables III, IV, and V.

Since Trétiakoff's thesis, lipoid swelling of nerve cells has been noted by several writers on Parkinsonism but always without emphasis. As von Braunmühl suggests, it may be one of the ways in which nerve cells, Camaged by the virus of encephalitis lethargica, degenerate and disappear.

Vacuolation of Nerve Cells.-Vacuolation of nerve cells also occurred more often in postencephalitic than in idiopathic cases but it was always quite a rare finding. This also is in agreement with Trétiakoff, who used various staining methods including a variant of Mallory's connective tissue stain and haematoxylin-eosin. Later workers, (e.g. Foix and Nicolesco) who relied more on Nissl's method, seem to lay more stress on vacuolation. Some confess that it is difficult to be certain, by this method, whether a vacuole does or does not contain a solid mass of acidophil protein, that is a hyaline inclusion of Lewy. However we found vacuoles in some cases (e.g. Case 31, F.W.) in which Lewy's inclusions were not seen in any of the pigmented cells as well as in cases of our control group. These vacuoles, which usually lie under the cell membrane, may be as large as, or even larger than, the nucleus. Vacuolation of this kind is a common finding in chromatolytic cells in the ventral horns of the spinal cord, and may be to some extent a fixation artifact. In our cases vacuoles were found so rarely that they were not considered of much importance.

Binucleated Nerve Cells.-Binucleated nerve cells, which also have been mentioned by other workers on Parkinsonism, were seen in the substantia nigra in three apparently post-encephalitic cases, one of which (No. 22) was also syphilitic (Fig. 3). One

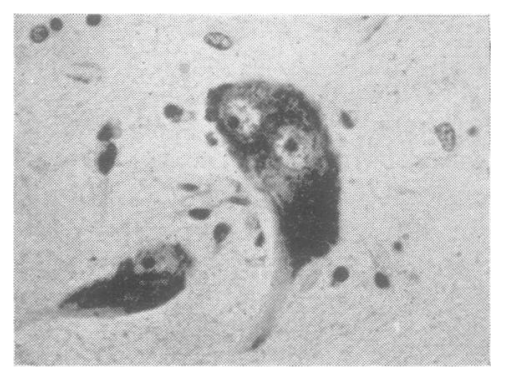

Fig. 3.-Case 31. Binucleated nerve cell in substantia nigra. Nissl stain. was also seen in the nucleus pontis in a case of idiopathic paralysis agitans. Binucleated Purkinje cells have been frequently seen in congenital and acquired syphilis and binucleated cortical nerve cells after cerebral trauma by Rand and Courville (1946) and by one of us (J.G.G.). If therefore seems probable that adult nerve cells may undergo this form of incomplete amitotic division when they are subjected to various types of noxa.

We do not consider any of these three types of change in any way specific for Parkinsonism.

Lewy's Spherical Hyaline Inclusions.-Lewy's spherical hyaline inclusions appear as rounded or oval condensations of cytoplasm, with a more or less concentric appearance. They always have a pale outer zone or halo of lighter staining, and many of the larger inclusions also contain a sharply defined core which is strongly acidophilic. These inclusions usually lie among the melanin granules which they seem to displace, but they may also be seen in cells containing little or no pigment. They are often single but several small spherical bodies may be seen in one cell. They vary in size from 5 to $25 \mu$. They appear quite non-granular and are thus distinguished from the rounded collections of lipochrome granules which have already been described. Their staining reactions are given in Table I. With toluidin blue or thionin, as used in the routine stain for Nissl granules, they are usually entirely unstained, but in some we may see a faint sky blue central core which contrasts in colour with the more purple Nissl granules and nucleo-protein (Hassler's "hell-blau Metachromasie"). In frozen sections stained with toluidin blue and mounted without passing through alcohol they may stain purple ( $\beta$ metachromasia, Pearse, 1953).

It is easy to miss the smaller inclusions with the Nissl stain, especially those which lie near the margin of the cell, and we have preferred cytoplasmic stains, especially those in which different colours correspond to different degrees of acidophilia, such as Heidenhain's azan, Masson's trichrome and Lendrum's phloxine-tartrazine. With all these methods the central core stains bright red, while the rest of the inclusion takes the more neutral colour, blue, green, or yellow, but always shows a paler outer halo (Figs. 4-7). We have been unable to see any anisotropism in this outer zone by any technique we have been able to use, e.g., frozen sections and different mountants. With haematoxylin and eosin also the central core stains more brightly red than the periphery. With iron haematoxylin and van Gieson, and with Mallory's phosphotungstic acid haematoxylin (Fig. 8) the con- 
TABLE I

STAINING REACTIONS OF INCLUSION BODIES

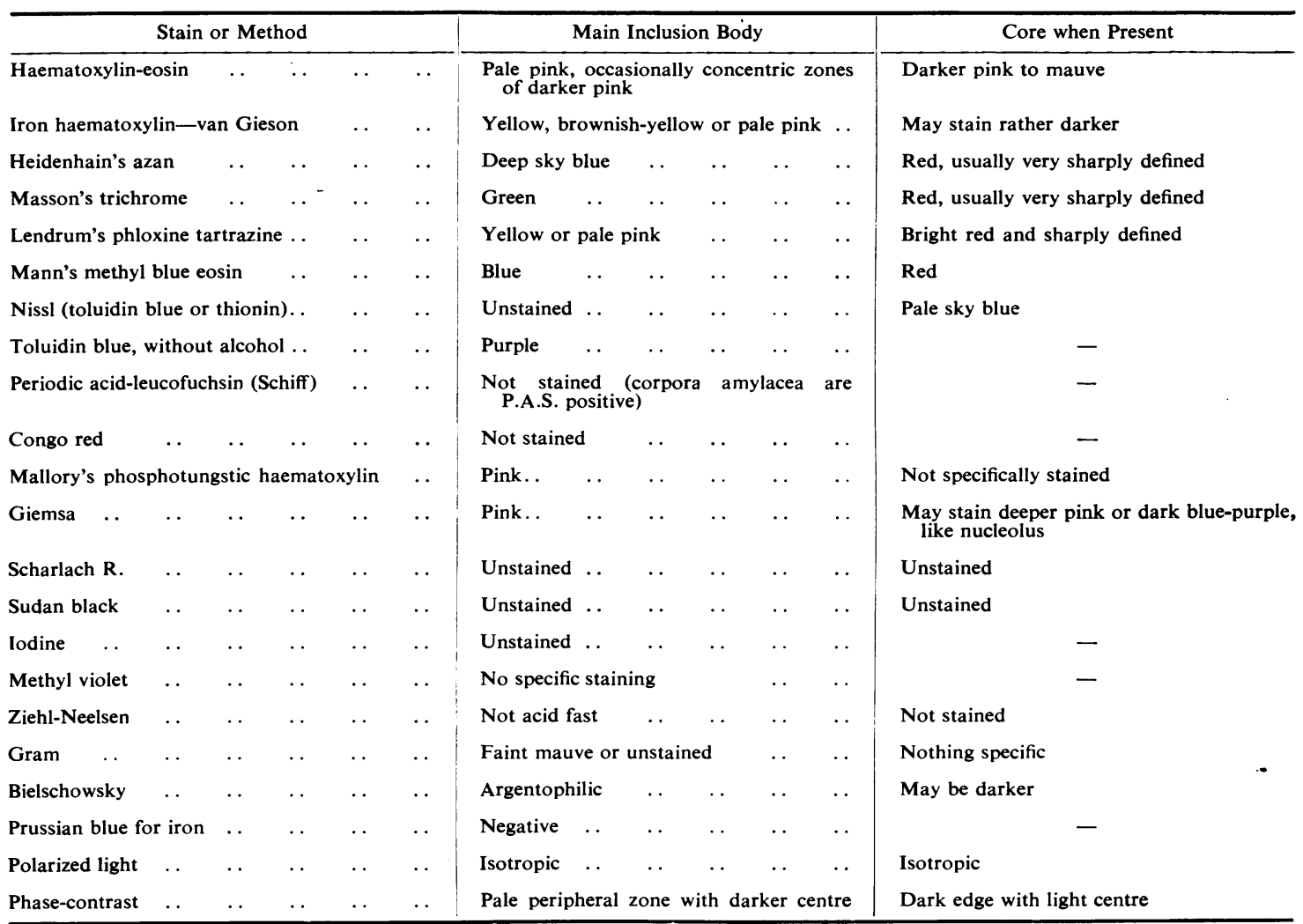

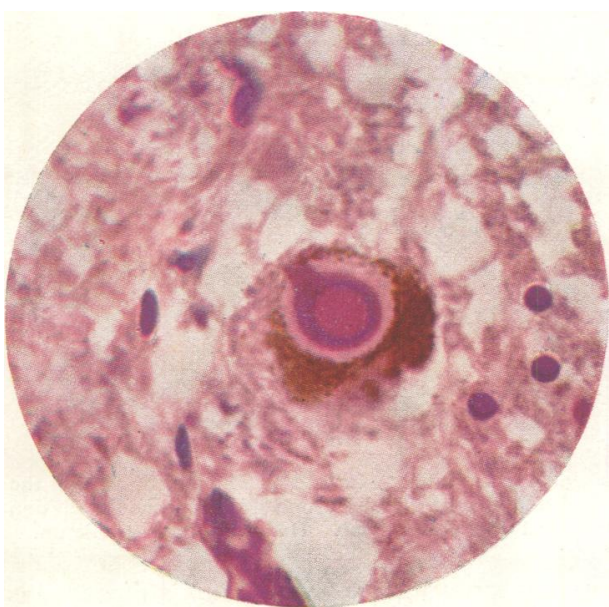

FIg. 4.-Case 4. Cell of the locus coeruleus containing concentric Lewy inclusion with an unusually large central core. Lendrum's phloxin-tartrazine method.

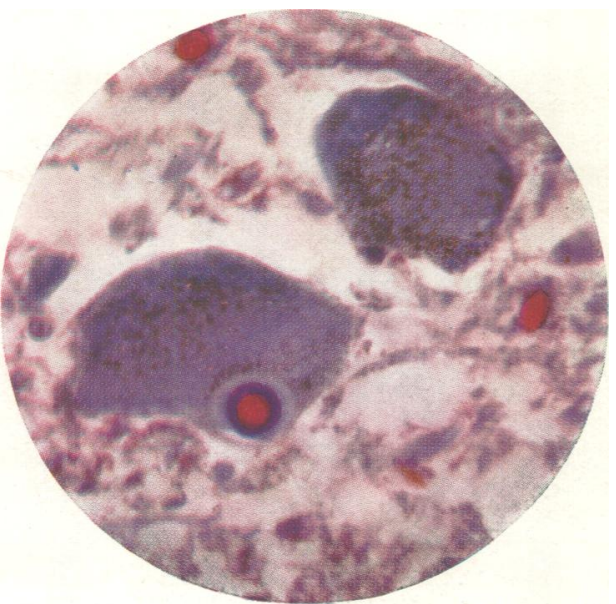

Fig. 5.-Case 4. Lewy inclusion in cell of the locus coeruleus showing typical concentric structure. Heidenhain's azan method. 


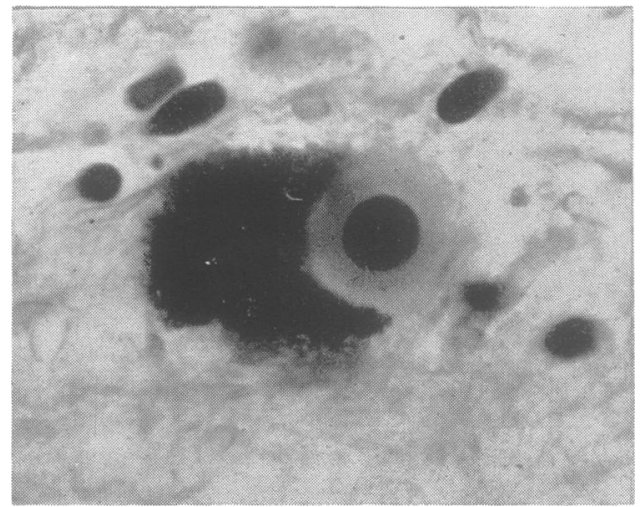

Fig. 6.-Case 9. Lewy inclusion in locus coeruleus showing a dark (bright red) central core in paler (yellow) body. Lendrum's phloxin-tartrazine stain. $\times 1150$.

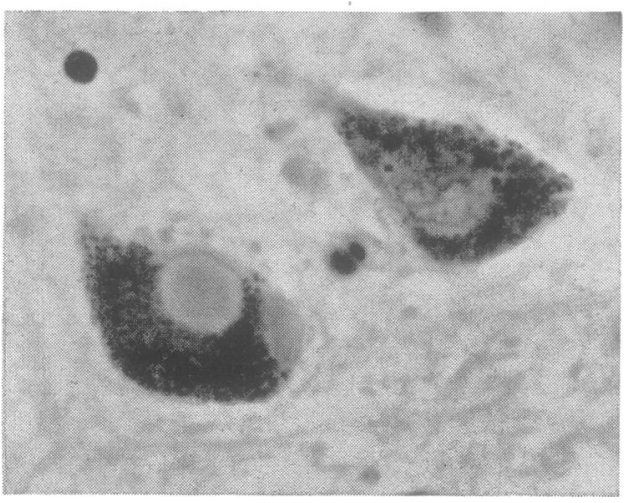

Fig. 7.-Case 10. Lewy inclusion in substantia nigra stained by haematoxylin-eosin. $\times \mathbf{7 3 0}$.

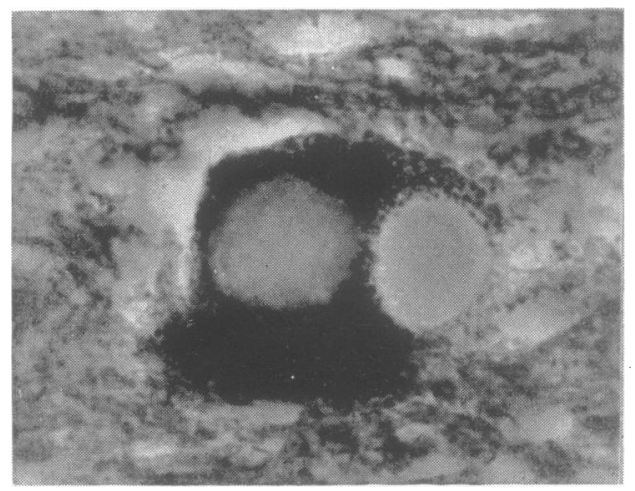

Fig. 8.-Case 32. Lewy inclusions (one out of focus) in cell of substantia nigra. Stained by Mallory's phosphotungstic acid haematoxylin.

centric structure of the inclusions is less well seen. Although the central core has similar staining reactions to the cytoplasmic inclusions seen in virus diseases (e.g. Negri bodies) the concentric structure of the peripheral zone distinguishes Lewy's bodies from virus inclusions. They do not stain specifically either by Schiff's periodic acid stain for polysaccharides or by any of the stains for amyloid or lipoid. The nerve cells containing the larger inclusions usually show chromatolysis, with eccentric nuclei.

As Hallervorden has suggested that these inclusions are related to the rounded argyrophilic bodies seen in the nerve cells of the cortex in Pick's lobar atrophy, we have examined the mid-brain and pons in two cases of Pick's disease. In both of these there was considerable loss of cells in the substantia nigra and many of the pigmented cells, both here and in the locus coeruleus, contained more or less rounded areas of homogeneous cytoplasm. These usually lay against the nucleus, which was deformed to a reniform shape and pushed against the cell membrane. Such areas lay between the nucleus and the melanin pigment, and not surrounded by melanin pigment like Lewy inclusions. In occasional cells, especially in the locus coeruleus, one or more smaller homogeneous areas were seen near the margin of the cell. In both situations these areas failed to show the halo of lighter staining which was so constantly seen in the Lewy inclusions ; and in spite of the abundance of 8 relatively large rounded homogeneous areas, especially in the cells of the substantia nigra, none showed any evidence of a central more hyaline core? (Fig. 9). The differences between Lewy's inclusions

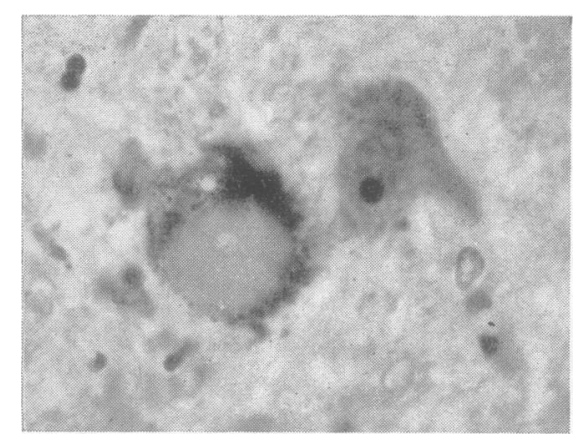

Fig. 9.-Pick's disease, Case 38. Pigmented cell of the substantia nigra showing rounded homogeneous inclusion typical of Pick's disease. Haematoxylin-van Gieson.

and the argentophil bodies of Pick's disease became quite obvious when polychrome stains such as azan and Lendrum's phloxin-tartrazine method were used; the confusion between them appears to have arisen from the too exclusive use of silver stains. 
Neurofibrillary Tangles. - Neurofibrillary tangles, as seen in the brain-stem, differ in some respects from those found in the cortex and hippocampus in Alzheimer's disease. In some of our cases the whole mid-brain and upper pons was embedded in paraffin, and could not therefore be stained by ordinary silver techniques. We used Braunmühl's, Bodian's, and Holmes's methods on this material without much success as most of the neurofibrillar tangles did not stain so darkly as the surrounding

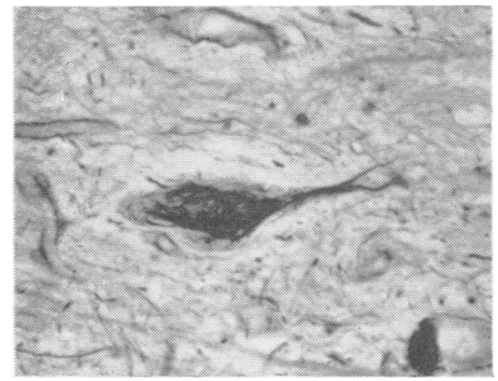

FIG. 10.-Case 31. Early neurofibrillary change in cell of substantia nigra. Holmes' silver method.

axones (Fig. 10). In such cases we depended on thionin, Lendrum's method, and Congo red (Divry, 1934) to demonstrate this change.

The earliest evidence of alterations in the neurofibrils was an unusual orientation of the Nissl and melanin granules in the apex of the cells of the substantia nigra, so that they lay in rows with clear lines between them. This appearance resembled somewhat the description given by Trétiakoff. At a rather later stage one side of the cell appeared normal, while the other, instead of Nissl granules, contained lines of highly refractile material running towards the dendrites (Fig. 11). At a still later stage

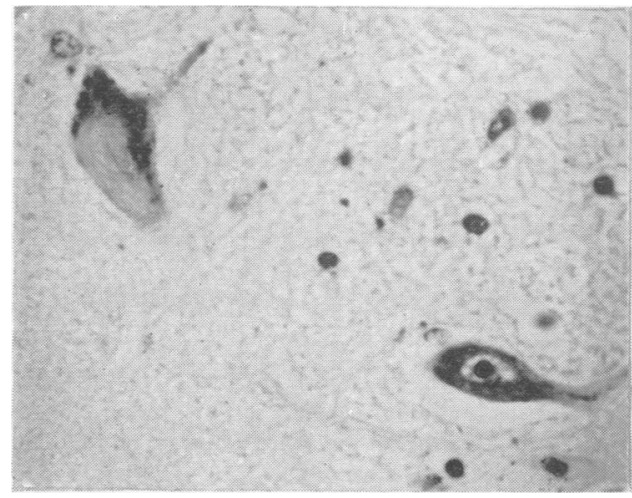

FIG. 11.-Case 31. Early neurofibrillary change in one side of a cell in the substantia nigra. Nissl stain. the whole cell became filled with a tangled skein of fibrillar structure which was haematoxophilic in varying degree. A few scattered melanin granules might be seen in or around the cells at this stage, and their presence might be helpful in finding these cells. At this stage the cell was usually rounded, oval, or triangular with a well-defined outline; it was often considerably larger than the surrounding normal cells and the nucleus had usually disappeared (Fig. 12).

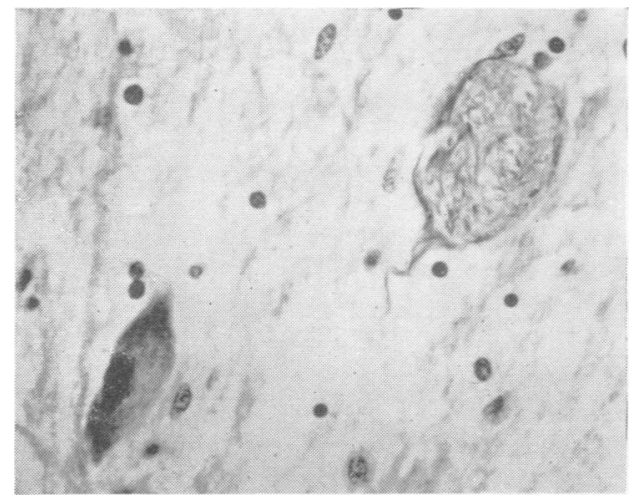

Fig. 12.-Case 34. Two cells of "formation cupuliforme", one showing neurofibrillary change. Haematoxylineosin.

The last stage was represented by an irregular, spherical, or triangular tangle of fibrils with no surrounding membrane, lying free in the tissues from which, with most staining methods, it could only be distinguished with difficulty (Figs. 13 and 14). It did not stain by basic anilin dyes, as in
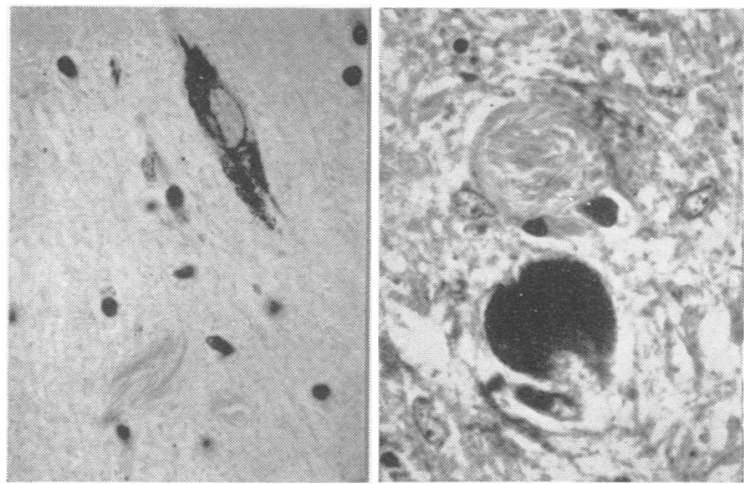

Fig. 13.-Case 31. Two cells of substantia nigra, one showing advanced neurofibrillary change. Nissl stain.
Fig. 14.-Case 31. Two cells of locus coeruleus, one showing neurofibrillary change. Lendrum's phloxintartrazine method. 
Nissl's method; with haematoxylin-eosin or phloxin-tartrazine it took the same pinkish colour as its surroundings but was distinguished from them by the orientation of the fibrils ; with Congo red its fibrils stained very feebly but showed a fairly bright anisotropism when examined under polarized light (Fig. 15). This anisotropism was also seen, although less brightly, with Lendrum's stain.

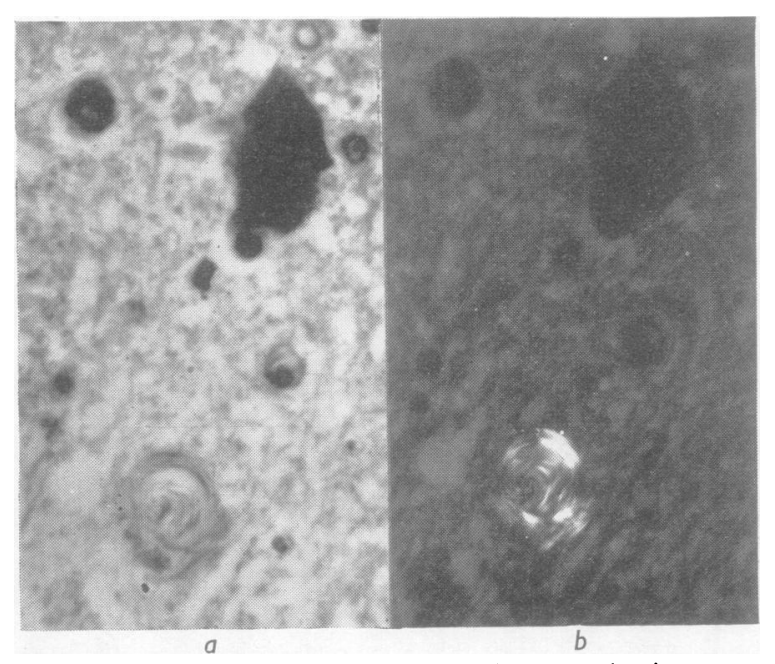

Fig. 15.-Case 31. Two cells of locus coeruleus, one showing neurofibrillary change. Congo red (a) ordinary light, $(b)$ polarized light, crossed Nicol prisms (Divry reaction).

In the cases in which frozen sections were stained by silver techniques the neurofibrillar tangles stainied similarly to those seen in Alzheimer's disease. The small hollow triangles commonly seen in the cortex in that disease were not found in the brain-stem, but one example was seen (in Case 34) in the hippocampus.

\section{Incidence of Spherical Inclusions and Neurofibrillary Tangles}

Spherical Inclusions.--Spherical inclusions in the cells of the substantia nigra were found in 18 of our 19 typical cases of paralysis agitans, whose ages at death ranged from 60 to 87 years. In the other case (No. 8) the brain was received torn across at the mid-brain level in such a way that we could make no sections through the substantia nigra, but typical inclusions were found in the locus coeruleus in this case. Thus in all these 19 cases typical spherical inclusions were found in the pigmented cells of the pons or mid-brain or in both areas. One of these (No. 5) was a case in which Parkinsonism was combined with Alzheimer's disease (Table II). Inclusions were also found in one case, aged 57 at death, which may have been post-encephalitic (No. 32). They were not found in the case of a woman (No. 30) aged 54 at death, with two years' history of paralysis agitans and no history of encephalitis. In this case there was very great cell loss and scarring in the substantia nigra; the locus coeruleus was not available (Table IV).

The incidence of these inclusions in different parts of the substantia nigra could not be assessed with any accuracy except in the cases in which serial sections were made. They were usually most abundant in the upper part of the nucleus, in which they were widely distributed, and were not confined to the zona compacta. Where they were most abundant it was not unusual to find several cells containing them in one high power $(4 \mathrm{~mm}$.) field, but many fields of the substantia nigra might be examined without any inclusions being seen. In general every section through the substantia nigra in these 20 cases was found to contain at least one cell inclusion. This was also true of sections through the main mass of the locus coeruleus. Therefore once their appearance under different staining conditions was recognized, they could be found without much difficulty. In addition to the pigmented cells of the substantia nigra and locus coeruleus, typical in- ${ }_{?}$ clusions were found in our material in the substantiå innominata (Case 32), in the nucleus of Rollep (Case 10), and in the oculomotor nucleus (Cases 98 and 31).

Neurofibrillary Tangles.-Neurofibrillary tangles in the pigmented cells of the pons and mid-brain were found in nine of the 10 cases in which there was a history of encephalitis, in one in which Parkinsonism was associated with amyotrophy and with attacks of forced adversive eye movements (No. 31), and in one case (No. 34) in which the clinical diagnosis was that of idiopathic paralysis agitans (Tables III and IV). In all these cases they were much less numerous than the cell inclusions in the idiopathic group. In a few places, especially in the locus coeruleus and in the rostro-lateral part of the substantia nigra, two such tangles, either in an earlier or later stage, could be seen in one high power field, but often sections through the substantia nigra or locus coeruleus were examined without any being found. In some cases cells showing neurofibrillary change were more widespread, for example in Case 27 many were seen in the hypothalamus. It is not surprising that the pigmented cells in the pons and mid-brain should undergo this neurofibrillary change, since they are known to be specially attacked in encephalitis lethargica. A similar change has been found in the 
TABLE II

NINETEEN CASES OF IDIOPATHIC PARALYSIS AGITANS

\begin{tabular}{|c|c|c|c|c|c|c|c|c|c|c|}
\hline \multirow{2}{*}{$\begin{array}{l}\text { Case } \\
\text { No. }\end{array}$} & \multirow{2}{*}{ Name } & \multirow{2}{*}{ Age } & \multirow{2}{*}{ Sex } & \multirow{2}{*}{ Hospital No. } & \multirow{2}{*}{$\begin{array}{l}\text { Duration of } \\
\text { Symptoms }\end{array}$} & \multicolumn{2}{|c|}{ Cell Loss } & \multicolumn{3}{|c|}{ Cell Changes } \\
\hline & & & & & & S.N. & L.C. & S.N. & L.C. & Elsewhere \\
\hline 1 & A.H. & 60 & $\mathbf{F}$ & R.677/52 & 10 years & + & 0 & I.B. + & I.B.+ & Binucleated cell $n$. pontis \\
\hline 2 & A.C. & 61 & $\mathbf{F}$ & N.H.48/21 & 3 years & ++ & 0 & I.B. \pm & I.B. + & Nil \\
\hline 3 & M.P. & 61 & $\mathbf{F}$ & N.H.72/31 & 20 years & + & - & I.B. ++ & - & Nil \\
\hline 4 & R.R. & 62 & $\mathbf{M}$ & N.H.84/51 & 6 years & + & 0 & I.B. ++ & I.B. ++ & Nil \\
\hline 5 & I.G. & 64 & $\mathbf{F}$ & N.H.28/36 & 2 years & + & - & I.B. ++ & - & Senile plaques in cortex \\
\hline 6 & E.P. & 64 & $\mathbf{F}$ & N.H.77/32 & 2 years & + & - & I.B. ++ & - & - \\
\hline 7 & G.H. & 66 & $\mathbf{M}$ & N.H.23/30 & 3 years & + & - & I.B. ++ & - & Nil \\
\hline 8 & E.T.* & 67 & $\mathbf{M}$ & N.H.67/47 & 4 months & - & Slight & - & I.B. ++ & Softening in putamen \\
\hline 9 & G.H.H. & 68 & $\mathbf{M}$ & R.301/51 & 6 years & \pm & \pm & I.B. ++ & I.B. + & I.B. oculomotor nucleus \\
\hline 10 & H.B. & 69 & $\mathbf{M}$ & R.4312/51 & 5 years & ++ & - & I.B.+ & - & I.B. Roller nucleus \\
\hline 11 & M.L. & ? & $\mathbf{F}$ & N.H. Ex/22 & $?$ & + & - & I.B. ++ & - & \\
\hline 12 & B.C. & $?$ & $?$ & N.H. Ex $/ 23$ & $?$ & + & & I.B. ++ & I.B. ++ & \\
\hline 13 & G.H. & $?$ & $?$ & NH Ex/22 & $?$ & $?$ & 0 & I.B. ++ & I.B. + & \\
\hline 14 & C.H.H. & $?$ & $?$ & NH. Ex/22 & $?$ & 0 & - & I.B. + & - & \\
\hline 15 & L.B. & 75 & $\mathbf{F}$ & R340/52 & 1 year & ? & 0 & I.B. ++ & I.B. + & \\
\hline 16 & G.C. & 79 & $\mathbf{M}$ & R.6188/51 & 4 years & + & - & I.B. + & - & \\
\hline 17 & H.B. & 80 & $\mathbf{M}$ & R.60/53 & $?$ & + & - & I.B. ++ & - & \\
\hline 18 & M.C. & 84 & F & R.4574/50 & 2 years & ++ & 0 & I.B. + & I.B. \pm & \\
\hline 19 & M.U. & 87 & $\mathbf{F}$ & R.5924/52 & 1 year & + & 0 & I.B.+ & I.B. + & \\
\hline
\end{tabular}

* W.R. positive in blood.

S.N. = Substantia nigra. $\quad$ L.C. $=$ Locus coeruleus. $\quad-=$ not available for adequate examination. I.B. $=$ Cytoplasmic inclusion bodies.

cortical nerve cells of young subjects who have suffered for several years from " subacute inclusion " (Malamud, Haymaker, and Pinkerton, 1950) or "subacute sclerosing" (Corsellis, 1951) encephalitis. The relation of neurofibrillary cell change to amyloid degeneration has been shown by Divry (1934). It is possible that in these cases it follows chronic poisoning of nerve cells by bacteria or viruses (von Braunmühl, 1949).

\section{Interpretation}

It is not very easy to interpret our findings in the light of those of other workers. At first sight it would appear that Lewy inclusions are the most common finding in cases of idiopathic paralysis agitans, and that neurofibrillary tangles are characteristic of post-encephalitic cases. The latter appears to be true for our material in so far as this change was very rarely seen in cases of idiopathic paralysis agitans. Even in the case in our series in which paralysis agitans was combined with Alzheimer's disease no neurofibrillary changes were seen in the mid-brain or pons, although they have been found there in other cases of Alzheimer's disease (Hallervorden, 1933). The only clinically typical case of paralysis agitans in our material in which neurofibrillary changes were seen was that of a patient of 66 (No. 34) with only three years' history of disability. Little attention has been paid to the presence of neurofibrillary tangles in idiopathic paralysis agitans since the work of Foix and Nicolesco (1925). Hallervorden (1933, 1935) and von Braunmühl (1949) were concerned entirely with post-encephalitic cases and neither Hassler (1938) nor Klaue (1940) saw these tangles. Foix and Nicolesco, however, describe neurofibrillary changes in both the substantia nigra and locus coeruleus in cases which they considered to be true Parkinson's disease.

It is possible, as Hallervorden (1935) suggests, that neurofibrillary changes tend to occur in younger, and Lewy's inclusions in older, subjects. Certainly, in our series, Lewy's inclusions were only seen in patients aged 56 or over, whereas neurofibrillary change was seen in one case aged 36 at death and not in any patient over 66 . In Hallervorden's 
TABLE III

TEN CASES OF POST-ENCEPHALITIC PARKINSONISM

\begin{tabular}{|c|c|c|c|c|c|c|c|c|c|c|}
\hline \multirow{2}{*}{$\begin{array}{l}\text { Case } \\
\text { No. }\end{array}$} & \multirow{2}{*}{ Name } & \multirow{2}{*}{ Age } & \multirow{2}{*}{ Sex } & \multirow{2}{*}{ Hospital No. } & \multirow{2}{*}{$\begin{array}{l}\text { Date of } \\
\text { Encephalitis } \\
\text { Lethargica }\end{array}$} & \multirow{2}{*}{$\begin{array}{c}\text { Duration } \\
\text { of } \\
\text { Symptoms } \\
\text { (years) }\end{array}$} & \multicolumn{2}{|c|}{ Cell Loss } & \multicolumn{2}{|c|}{ Cell Changes } \\
\hline & & & & & & & S.N. & L.C. & S.N. & L.C. \\
\hline 20 & J.C. & 33 & $\mathbf{M}$ & N.H.66/28 & 1924 & 4 & ++ & + & $\mathrm{Nil}$ & $\mathrm{Nil}$ \\
\hline 21 & F.P. & 36 & $\mathbf{M}$ & N.H.35/38 & 1921 & 9 & $+t+$ & 0 & Saccules ; tangles & Tangles \\
\hline 22 & *J.H. & 46 & $\mathbf{M}$ & N.H.67/33 & 1921 & 3 & ++ & - & Tangles ; binucleated cell & 一 \\
\hline 23 & W.W. & 47 & $\mathbf{M}$ & N.H.27/33 & 1922 & 9 & ++ & - & Saccules ; tangles & - \\
\hline 24 & F.T. & 48 & $\mathbf{M}$ & N.H. Ex/52 & 1922 & 28 & $+t$ & + & Tangles + & Tangles ++ \\
\hline 25 & L.T. & 51 & $\mathbf{F}$ & R.1804/53 & 1921 & $30+$ & $+t$ & 0 & Binucleated cells & Tangles \\
\hline 26 & A.T. & 52 & $\mathbf{F}$ & N.H.92/32 & 1924 & 4 & ++ & + & Saccules ; tangles & 0 \\
\hline 27 & L.W. & 54 & $F$ & R.547/49 & 1923 & 25 & +++ & - & Tangles ++ & 一 \\
\hline 28 & A.S. & 62 & $\mathbf{F}$ & $\mathbf{R} 225 / 50$ & 1920 & 30 & +++ & \pm & Tangles & Tangles \\
\hline 29 & F.D. & 65 & $\mathbf{M}$ & R.5230/50 & 1918 & $30+$ & +++ & \pm & Saccules ; tangles & Tangles \\
\hline
\end{tabular}

*W.R. repeatedly positive. S.N. = Substantia nigra. L.C. = Locus coeruleus. $\quad-=$ Not available for adequate examination.

TABLE IV

FIVE CASES OF ATYPICAL PARKINSONISM

\begin{tabular}{|c|c|c|c|c|c|c|c|c|c|}
\hline \multirow{2}{*}{$\begin{array}{l}\text { Case } \\
\text { No. }\end{array}$} & \multirow{2}{*}{$\begin{array}{l}\text { Name and } \\
\text { Hospital No. }\end{array}$} & \multirow{2}{*}{ Age } & \multirow{2}{*}{ Sex } & \multirow{2}{*}{ Type of Disease } & \multicolumn{2}{|c|}{ Cell Loss } & \multicolumn{2}{|c|}{ Cell Changes } & \multirow{2}{*}{ Other Findings in C.N.S. } \\
\hline & & & & & S.N. & L.C. & S.N. & L.C. & \\
\hline 30 & $\begin{array}{c}\text { C.B. } \\
(\text { N.H.15/35) }\end{array}$ & 54 & $\mathrm{~F}$ & Parkinsonism 2 years & ++ & - & Nil & - & $\begin{array}{l}\text { Diffuse cell loss }+ \text { gliosis in } \\
\text { globus pallidus }\end{array}$ \\
\hline 31 & $\begin{array}{l}\text { F.W. } \\
\text { (N.H.Ex/51) }\end{array}$ & $\begin{array}{l}56 \\
(b)\end{array}$ & $\mathbf{M}$ & $\begin{array}{l}\text { Parkinsonism. Adver- } \\
\text { sive eye attacks } \\
\text { Amyotrophy } 12 \text { years }\end{array}$ & + & 0 & $\begin{array}{c}\text { Saccules tan } \\
\text { Binuclear } \\
\text { nerve cell }\end{array}$ & les + & $\begin{array}{l}\text { Atrophy anterior horn cells ; no } \\
\text { tract lesions; basal ganglia } \\
\text { normal; } \\
\text { nucleus }\end{array}$ \\
\hline 32 & $\begin{array}{l}\text { R.M. } \\
(\mathbf{R} .398 \mathrm{~A} / 51)\end{array}$ & $\begin{array}{l}57 \\
\text { (b) }\end{array}$ & $\mathbf{M}$ & $\begin{array}{l}\text { Parkinsonism } 23 \text { years } \\
\text { ? Encephalitis, } 1926\end{array}$ & + & + & $\begin{array}{l}\text { Inclusio } \\
++\end{array}$ & s & $\begin{array}{l}\text { I.B. substantia innominatace } \\
\begin{array}{l}\text { Plaques of } \\
\text { cerebrum ; } \\
\text { nerve roots }\end{array}\end{array}$ \\
\hline 33 & $\begin{array}{l}\text { G.H. } \\
\text { (N.H. Ex./47) }\end{array}$ & $\begin{array}{l}59 \\
(a)\end{array}$ & $\mathbf{M}$ & $\begin{array}{l}\text { Cerebellar symptoms } \\
5 \text { years ; Parkinson- } \\
\text { ism less than } 1 \text { year }\end{array}$ & + & 0 & Nil & Nil & $\begin{array}{l}\text { Olivo-ponto-cerebellar degenera- } \\
\text { tion; Gliosis putamen; cell } \\
\text { loss-N.C.M. thalamus }\end{array}$ \\
\hline 34 & $\begin{array}{l}\text { C.F. } \\
(R .569 / 49)\end{array}$ & 66 & $\mathbf{M}$ & Parkinsonism 3 years & +++ & ++ & Tangles & Nil & Tangles in hippocampus \\
\hline
\end{tabular}

(a) Previously reported by Critchley and Greenfield (1948) Brain, 71, 343.

(b) To be reported in full.

S.N. = Substantia nigra. $\quad$ L.C. $=$ Locus coeruleus. $\quad-=$ Not available for adequate examination.

series a patient aged 11 showed this change in especially severe and widespread manner. It is thus evidently not a change confined to older brains, as Lewy's inclusions may be. On the other hand both Hassler and we ourselves have been unable to find typical Lewy inclusions in brains from old patients who showed no evidence of Parkinsonism. In only one of our cases (No. 31) did we find both neurofibrillary changes and Lewy's inclusions. In this, probably post-encephalitic, case neurofibrillary tangles were numerous, and Lewy inclusions were only seen in one cell in the oculomotor nucleus.
The brain-stem lesions in Parkinsonism may now be considered in relation to the three questions already posed.

(1) Are the lesions of idiopathic paralysis agitans, as Foix and Nicolesco suggested, an abnormal localization of the processes of senility? The answer to this question is definitely in the negative since the type of cell degeneration with Lewy's inclusions is not a common senile change.

(2) Are the changes found in idiopathic paralysis agitans specific for the disease or in any way characteristic of it? The first part of this question cannot be answered definitely in the affirmative 
TABLE V

TWENTY-TWO CONTROL CASES WITHOUT PARKINSONISM

\begin{tabular}{|c|c|c|c|c|c|c|c|c|c|}
\hline \multirow{2}{*}{$\begin{array}{l}\text { Case } \\
\text { No. }\end{array}$} & \multirow{2}{*}{ Name } & \multirow{2}{*}{ Age } & \multirow{2}{*}{ Sex } & \multirow{2}{*}{$\begin{array}{c}\text { Hospital } \\
\text { No. }\end{array}$} & \multirow{2}{*}{ Diagnosis } & \multicolumn{2}{|c|}{ Cell Loss } & \multicolumn{2}{|l|}{ Cell Changes } \\
\hline & & & & & & S.N. & L.C. & S.N. & L.C. \\
\hline $\begin{array}{l}35 \\
36 \\
37 \\
38\end{array}$ & $\begin{array}{l}\text { T.S. } \\
\text { H.B. } \\
\text { G.F. } \\
\text { F.M.P. }\end{array}$ & $\begin{array}{l}50 \\
54 \\
56 \\
62\end{array}$ & $\begin{array}{l}\mathbf{M} \\
\mathbf{M} \\
\mathbf{F} \\
\mathbf{M}\end{array}$ & $\begin{array}{l}\text { R.2/51 } \\
\text { R.506/50 } \\
\text { R.316/50 } \\
\text { N.H. Ext. } / 45\end{array}$ & $\begin{array}{l}\text { Atheroma, multiple infarcts of brain } \\
\text { Meningioma, brain } \\
\text { Subacute combined degeneration } \\
\text { Pick's disease }\end{array}$ & $\begin{array}{l}+ \\
\mathbf{0} \\
\mathbf{0} \\
+\end{array}$ & $\begin{array}{l}\frac{0}{2} \\
\dot{?}\end{array}$ & $\begin{array}{l}\text { Infarct. Depigmentation } \\
\text { 0 } \\
\text { Depigmentation } \\
\text { Spherical homogeneous } \\
\text { bodies }\end{array}$ & $\frac{0}{0}$ \\
\hline $\begin{array}{l}39 \\
40 \\
41 \\
42\end{array}$ & $\begin{array}{l}\text { A.H. } \\
\text { H.J. } \\
\text { M.B. } \\
\text { T.H. }\end{array}$ & $\begin{array}{l}62 \\
63 \\
64 \\
64\end{array}$ & $\begin{array}{l}\mathbf{M} \\
\mathbf{M} \\
\mathbf{F} \\
\mathbf{M}\end{array}$ & $\begin{array}{l}\text { R.534/52 } \\
\text { R. } 5692 / 50 \\
\text { R.107/51 } \\
\text { R.298/52 }\end{array}$ & $\begin{array}{l}\text { Atheroma, anterior cerebral thrombosis } \\
\text { Atheroma, multiple infarcts } \\
\text { Disseminated sclerosis } \\
\text { Motor neuron disease }\end{array}$ & $\begin{array}{l}\mathbf{0} \\
\mathbf{0} \\
\mathbf{0} \\
\pm\end{array}$ & $\begin{array}{l}0 \\
0 \\
-\end{array}$ & $\begin{array}{c}0 \\
0 \\
\text { Intranuclear inclusions } \\
\text { Depigmentation. Oc- } \\
\text { casional intranuclear } \\
\text { inclusion }\end{array}$ & $\begin{array}{l}\mathbf{0} \\
\mathbf{0} \\
\overline{-}\end{array}$ \\
\hline $\begin{array}{l}43 \\
44 \\
45 \\
46\end{array}$ & $\begin{array}{l}\text { A.F. }(c) \\
\text { W.N. } \\
\text { E.B. } \\
\text { J.J. }\end{array}$ & $\begin{array}{l}65 \\
64 \\
66 \\
68\end{array}$ & $\begin{array}{l}\mathbf{M} \\
\mathbf{M} \\
\mathbf{F}\end{array}$ & $\begin{array}{l}\text { N.H. Ext. } / 29 \\
\text { R.258A } / 50 \\
\text { R.186/52 } \\
\text { N.H. Ext. } / 49\end{array}$ & $\begin{array}{l}\text { Senile chorea } \\
\text { Old poliomyelitis } \\
\text { Pseudo-bulbar palsy } \\
\text { Huntington's chorea }\end{array}$ & $\begin{array}{l}\mathbf{0} \\
\mathbf{0} \\
\mathbf{0} \\
\mathbf{0} \\
\mathbf{0}\end{array}$ & $\begin{array}{l}0 \\
0 \\
\bar{y}\end{array}$ & $\begin{array}{l}0 \\
\text { One atypical inclusion } \\
\text { Depigmentation } \\
0\end{array}$ & $\begin{array}{c}0 \\
\frac{0}{-} \\
\text { One }\end{array}$ \\
\hline 47 & E.G. & 69 & $\mathbf{F}$ & $\mathbf{R . 4 8 0 8 / 5 0}$ & Spinal meningioma & 0 & + & Depigmentation & $\begin{array}{l}\text { One aty- } \\
\text { pical in- } \\
\text { clusion }\end{array}$ \\
\hline $\begin{array}{l}48 \\
49\end{array}$ & $\begin{array}{l}\text { M.B. } \\
\text { T.B. }\end{array}$ & $\begin{array}{l}69 \\
70\end{array}$ & $\mathbf{F}$ & $\begin{array}{l}\text { R.4739/51 } \\
\mathbf{R} .851 / 52\end{array}$ & $\begin{array}{l}\text { Tabes dorsalis } \\
\text { Pseudo-bulbar palsy }\end{array}$ & $\begin{array}{c}0 \\
\text { Some } \\
\end{array}$ & Depig- & Saccules 0 & $\overline{0}$ \\
\hline $\begin{array}{l}50 \\
51\end{array}$ & $\begin{array}{l}\text { S.T. } \\
\text { M.B. }\end{array}$ & $\begin{array}{l}70 \\
70\end{array}$ & $\begin{array}{l}\mathbf{F} \\
\mathbf{F}\end{array}$ & $\begin{array}{l}\text { R.180/51 } \\
\text { R.2969/52 }\end{array}$ & $\begin{array}{l}\text { Anterior spinal thrombosis } \\
\text { Disseminated sclerosis }\end{array}$ & $\begin{array}{c}\text { vascurar } \\
\text { loss } \\
0 \\
0\end{array}$ & tion & $\begin{array}{l}\text { Intranuclear inclusions } \\
\text { Plaque of disseminated } \\
\text { sclerosis }\end{array}$ & $\overline{-}$ \\
\hline $\begin{array}{l}52 \\
53\end{array}$ & $\begin{array}{l}\text { H.S.-T. } \\
\text { S.P. }\end{array}$ & $\begin{array}{l}78 \\
78\end{array}$ & $\begin{array}{l}\mathbf{M} \\
\mathbf{F}\end{array}$ & $\begin{array}{l}\text { R.34/52 } \\
\text { R.475/52 }\end{array}$ & $\begin{array}{l}\text { Healing pyogenic meningitis } \\
\text { Spinal meningioma. Multiple infarcts }\end{array}$ & $\begin{array}{l}\mathbf{0} \\
\pm\end{array}$ & $\overline{+}$ & $\begin{array}{l}0 \\
\text { Vacuolation and depigm }\end{array}$ & entation \\
\hline $\begin{array}{l}54 \\
55 \\
56\end{array}$ & $\begin{array}{l}\text { M.B. }(d) \\
\text { T.G. } \\
\text { H.B. }\end{array}$ & $\begin{array}{l}78 \\
87 \\
88\end{array}$ & $\begin{array}{l}\mathbf{F} \\
\mathbf{M}\end{array}$ & $\begin{array}{l}\text { N.H. Ext./41 } \\
\text { R.848/52 } \\
\text { N.H.11/26 }\end{array}$ & $\begin{array}{l}\text { Familial cerebellar degeneration } \\
\text { Pseudo-bulbar palsy } \\
\text { Hemiballismus }\end{array}$ & $\begin{array}{l}\mathbf{0} \\
\pm \\
\mathbf{0}\end{array}$ & $\overline{-}$ & $\begin{array}{l}\text { Softenings } \\
\text { Vacuoles } \\
0\end{array}$ & $\overline{\overline{0}}$ \\
\hline
\end{tabular}

(c) Previously reported by Alcock (1936) Brain, 59, 376.

(d) Previously reported by Parkes Weber and Greenfield (1942) Brain, 65, 220.

$$
\text { S.N. = Substantia nigra. } \quad \text { L.C. }=\text { Locus coeruleus. }
$$

since inclusions, which may resemble Lewy's bodies, have been found in the pigmented cells of the brain-stem in two cases of status pigmentatus (Holfand, 1935; van Bogaert, 1939-40). The combination of loss of cells in certain fairly well defined cell groups in the substantia nigra, with numerous inclusions of the Lewy type, as defined by us, in the pigmented colls of the brain-stem is, however, quite characteristic of paralysis agitans and occurs, so far as we know, in no other disease.

(3) Are the differences between the lesions found in idiopathic paralysis agitans on the one hand and those in post-encephalitic Parkinsonism on the other hand qualitative or only quantitative ? While we do not accept the conclusion, drawn by Spatz from the work of Klaue in his laboratory, that the histological changes in these two conditions were so similar as to suggest a common aetiology, we cannot make any sharp qualitative distinction between the two diseases. Our observations do not allow us to place all cases with Lewy bodies in the idiopathic group and all those with neurofibrillary tangles in the post-encephalitic group, although for the great majority of our cases this distinction holds; nor does the literature support this distinction, although few writers have laid emphasis on both types of cell change. Our material is not so large as that examined by several continental workers and may be loaded in one or the other direction. For example we had no cases of typical idiopathic paralysis agitans dying under the age of 60 . On the other hand the age at death of our post-encephalitic cases varied from 33 to 65 with an average of 49.4 years. This is probably older than that in previously reported series since the latest date of the original attack was 1924. Our observations do not entirely rule out Hallervorden's suggestion that the difference in histological findings depends on age rather than on aetiology, but they give no support to his suggestion that Lewy inclusions and neurofibrillary tangles are two stages of the same process. Before a final answer can be given to these questions it will be necessary to examine a larger series of cases of Parkinsonism, including some in the younger age groups, with special attention to the changes in the pigmented cells of the mid-brain and pons.

\section{Summary}

The pigmented cells of the brain-stem, especially those in the substantia nigra and locus coeruleus, have been examined in 19 cases of idiopathic 
paralysis agitans, 10 cases of Parkinsonism with a history of an attack of encephalitis between the years 1918 and 1924, and five cases of Parkinsonism of uncertain aetiology. Five types of change were found in these cells. (1) Saccular distension by lipochrome granules along with disappearance of Nissl granules, melanin, and nucleus ; (2) vacuolation, which was considered unimportant; (3) binucleated nerve cells, which were very rare ; (4) Lewy's spherical concentric hyaline inclusions; (5) neurofibrillary tangles, somewhat similar to those seen in Alzheimer's disease, but unaccompanied by senile plaques.

The first three types were seen in post-encephalitic cases and in occasional cases in the control group. Lewy's hyaline inclusions were found in all of our cases of typical idiopathic paralysis agitans, and in one complicated case which may have been post-encephalitic. Neurofibrillary tangles were found in nine post-encephalitic cases, in one case associated with amyotrophy, which may have been post-encephalitic, and in one case which was clinically idiopathic. In one case of Parkinsonism associated with olivo-ponto-cerebellar degeneration, and in 22 cases in the age group 50 to 90 years, with no signs of Parkinsonism, neither of the last two types of cell change could be found in the pigmented cells of the brain-stem. The significance of these findings is discussed in relation to the literature on the subject.

Our thanks are due to the medical and surgical staff of the National Hospital, Queen Square, The Radcliffe
Infirmary and Cowley Road Hospital, Oxford, who have given us facilities for collecting material ; to Mr. Ewan Middleton and Mr. Ronald Beesley for their careful and enthusiastic technical assistance, and to Miss M. M. L. Prichard, D. Phil., and Mr. J. A. Mills for excellent photomicrographs.

\section{REFERENCES}

Alcock, N. S. (1936). Brain, 59, 376.

Beheim-Schwarzbach, D. (1952). J. nerv. ment. Dis., 116, 619.

Benda, C. E., and Cobb, S. (1942). Medicine, 21, 95.

Bogaert, L. van (1939-40). Rev. neurol., Paris, 72, 448.

Braunmühl, A. von (1949). Arch. Psychiat. Nervenkr., 181, 543.

Corsellis, J. A. N. (1951). J. ment. Sci., 97, 570.

Critchley, M., and Greenfield, J. G. (1948). Brain, 71, 343.

Davison, C. (1942). Res. Publ. Ass. nerv. ment. Dis., 21, 267.

Denny-Brown, D. (1946). Diseases of the Basal Ganglia and Subthalamic Nuclei. Oxford University Press, New York.

Divry, P. (1934). J. belge Neurol. Psychiat., 34, 197.

Fényes, I. (1932). Arch. Psychiat. Nervenkr., 96, 700.

Foix, C., and Nicolesco, J. (1925). Les noyaux gris centraux et la région mésencéphalo-sous-optique. Masson, Paris.

Hallervorden, J. (1933). Klin. Wschr., 12, 692.

- (1935). Dtsch. Z. Nervenheilk., 136, 68.

Hassler, R. (1937). J. Psychol. Neurol., Lpz., 48, 1.

(1938). Ibid., 48, 387

Helfand, M. (1935). J. nerv. ment. Dis., 81, 662.

Klaue, R. (1940). Arch. Psychiat., Nervenkr., 111, 251.

Lafora, G. R. (1911). Virchows Arch., 205, 295.

- (1913a). Trab. Lab. Invest. biol. Univ. Madr., 11, 29.

Lewy, F. H. (1912). Handbuch der Neurologie, ed. M. Lewandowsky, vol. 3, p. 920 . Springer, Berlin.

--(1913). Disch. Z. Nervenheilk., 50, 50. Die Lehre vom Tonus und der Bewegung. Springer, Berlin.

Malamud, N., Haymaker, W., and Pinkerton, H. (1950). Amer. J.ণ Path., 26, 133.

Pearse, A. G. E. (1953). Histochemistry, Churchill, London.

Rand, C. W., and Courville, C. B. (1946). Arch. Neurol. Psychiat. Chicago, 55, 79.

Riley, H. A. (1943). An Atlas of the Basal Ganglia, Brain Stem and Spinal Cord. Williams and Wilkins, Baltimore.

Trétiakoff, C. (1919). Contribution à l'étude de l'Anatomie pathologique du Locus niger de Soemmering. Thèse de Paris.

Weber, F. Parkes, and Greenfield, J. G. (1942). Brain, 65, 220. 